\title{
Synthesis of Barium Ferrates in Oxygen
}

\author{
Taki Negas and Robert S. Roth \\ Institute for Materials Research, National Bureau of Standards, \\ Washington, D.C. 20234
}

(April 9, 1969)

\begin{abstract}
Phase relations in the system $\mathrm{BaO}-\mathrm{Fe}_{2} \mathrm{O}_{3}-$ " $\mathrm{FeO}_{2}$ " at 1 atm $\left(1 \mathrm{~atm}=1.013 \times 10^{5} \mathrm{~N} / \mathrm{m}^{2}\right)$ oxygen and between 800 to $1050{ }^{\circ} \mathrm{C}$ are shown in the vicinity (high $\mathrm{Ba}$ portion) of the $1: 1$ cation-cation ratio composition. A hexagonal $\mathrm{BaTiO}_{3}$-like phase, $\mathrm{BaFeO}_{3-X}(a=5.676 \AA, c=13.934 \AA)$, exists below $960^{\circ} \mathrm{C}$. A perovskite-like phase $\mathrm{BaFeO}_{3-X^{\prime}}$ occurs between 960 and $1050^{\circ} \mathrm{C}$. Single-phase tetragonal perovskite can be obtained at room temperature by quenching compositions with $\mathrm{Ba}-\mathrm{Fe}$ ratios of 67:66 $\left(a=3.985 \AA, c=4.005 \AA, 1000{ }^{\circ} \mathrm{C}\right)$ and $27: 26\left(a=3.988 \AA, c=4.003 \AA, 1000{ }^{\circ} \mathrm{C}\right)$ from above $960{ }^{\circ} \mathrm{C}$. At the $17: 16$ ratio, single phase cubic perovskite $\left(a=3.994 \AA, 1000{ }^{\circ} \mathrm{C}\right)$, can be synthesized. Influence of temperature, additions of barium, and use of Pt-containers on phase relations are discussed.
\end{abstract}

Key words: Ferrates; hexagonal barium ferrate; perovskite; phase equilibria; tetravalent iron.

\section{Introduction}

Mixed alkaline earth-transition metal oxides are of particular importance because of their interesting electrical and magnetic properties. Characterization of such materials through phase equilibrium and x-ray diffraction studies is complicated by the tendency of the transition metal to exist in disproportioned oxidation states within a single phase. Variable oxygen stoichiometries, controlled by temperature and oxygen pressure result. The 1:1 cation-cation barium ferrates are excellent examples of this phenomenon. Tetravalent iron has been confirmed in phases within the $\mathrm{BaFeO}_{2.5-3.0}$ compositional range by MacChesney et al. [1] ${ }^{1}$, and Gallagher et al. [2], using magnetic studies and the Mössbauer technique. Some inconsistencies, however, exist concerning the nature of the phases within this compositional range. Erchak et al. [3], reported the compound $\mathrm{BaFeO}_{2.62}\left(\mathrm{Ba}_{8} \mathrm{Fe}_{2}^{4+} \mathrm{Fe}_{6}^{3+} \mathrm{O}_{21}\right)$ which was thought to be a cubic perovskite $(a=8.05 \AA)$. Subsequently, Malinofsky and Kedesdy [4] showed that this phase is not cubic, but is actually analogous to the hexagonal polymorph of $\mathrm{BaTiO}_{3}$ [5] with $a=5.68$ $\AA$ and $c=13.86 \AA$. They also reported a tetragonal perovskite polymorph, admixed with the hexagonal form, with $a=3.98 \AA$ and $c=4.01 \AA$. This mixture was prepared by heating the hexagonal form at $1275^{\circ} \mathrm{C}$ in oxygen and slow-cooling. MacChesney, et al. [1], and Gallagher, et al. [2], prepared hexagonal forms in the $\mathrm{BaFeO}_{2.74-2.95}$ range using oxygen pressures from 0.2 to $2400 \mathrm{~atm}$ and generally below $850{ }^{\circ} \mathrm{C}$. Gushee

'Figures in brackets indicate the literature references at the end of this paper. et al. [6], reported a $\mathrm{BaFeO}_{2.72}$ hexagonal form with $a=5.76 \AA$ and $c=13.9 \AA$ while Goto and Takada [7] synthesized a $2 \mathrm{BaO} \cdot \mathrm{Fe}_{2} \mathrm{O}_{3}$ phase with a melting point at $1370{ }^{\circ} \mathrm{C}$ in $1 \mathrm{~atm} \mathrm{O}_{2}$. The latter phase was reported as cubic $(a=8.07 \AA)$ but is most likely a hexagonal barium ferrate similar to that reported by Erchak et al. [3], and originally thought to be a cubic perovskite with $a^{\prime}=2 a_{\text {cub }}$.

Mori $[8,9]$ reported a number of $\mathrm{BaFeO}_{3-X}$ phases with $X$ values ranging from 0.50 to 0.10 . These were prepared in air and 1 atm oxygen using quenching and slow-cooling techniques within the 25 to $1080^{\circ} \mathrm{C}$ range. A hexagonal $\mathrm{BaTiO}_{3}$-like phase was found by quenching from below $950{ }^{\circ} \mathrm{C}$ in oxygen. Above this temperature a transitory cubic form was obtained after a $\frac{1}{2}$-hr heating time. With longer heating times this form converted to a triclinic form through a rhombohedral form. Heating a $2 \mathrm{BaCO}_{3}: \mathrm{Fe}_{2} \mathrm{O}_{3}$ mixture at $1080{ }^{\circ} \mathrm{C}$ in oxygen for $\frac{1}{2}-\mathrm{hr}$ and quenching also produced a cubic form, $\mathrm{BaFeO}_{2.75}$, which upon further heating converted to a tetragonal phase, $\mathrm{BaFeO}_{2.81}$, through a series of tetragonal phases with lower oxygen contents. The $\mathrm{BaFeO}_{2.81}$ phase was not of the simple tetragonal perovskite type as its powder pattern gave evidence of superstructure lines. Final equilibration products were not indicated and difficulty was encountered in reproducing each phase, in terms of symmetry and oxygen content, by the quenching method.

Although the existence of the hexagonal form is well documented, synthesis of a stable single-phase tetragonal perovskite or a stable, truly cubic perovskite has not been demonstrated. This study was conducted 
to examine the latter possibility and, therefore, considers only the existence and stabilities of phases encountered. Chemical analyses establishing $\mathrm{Fe}^{4+}: \mathrm{Fe}^{3+}$ ratios (oxygen concentration) and Mössbauer data will be reported in the future.

\section{Experimental Procedure}

Starting material was prepared from appropriately weighed $\left( \pm 0.1 \mathrm{mg}\right.$ ) quantities of $\mathrm{BaCO}_{3}$ and $\mathrm{Fe}_{2} \mathrm{O}_{3}$. These were hand mixed under acetone, packed in gold envelopes, and calcined in air at $800{ }^{\circ} \mathrm{C}$ for two weeks with periodic remixing and reheating. Gold was used as the container instead of platinum because of the tendency of uncombined $\mathrm{BaCO}_{3}$ to react with the latter. Another problem with platinum will be discussed later. Calcined specimens were equilibrated at elevated temperatures in 1 atm ( 1 atm $=1.013 \times 10^{5} \mathrm{~N} / \mathrm{m}^{2}$ ) oxygen using the quench method. A vertical tube, resistance type, furnace, modified for vacuum and gas flow capability with endclosures and "O"-ring seals, was used for the quenching experiments. Oxygen was passed through the furnace at $10^{-6} \mathrm{~m}^{3} / \mathrm{s}$ flow rate. Open gold envelopes were used as containers to $1050{ }^{\circ} \mathrm{C}$. A few experiments were conducted above $1050{ }^{\circ} \mathrm{C}$ using platinum. Temperatures were measured with $\mathrm{Pt}-\mathrm{Pt} 10$ percent $\mathrm{Rh}$ thermocouples calibrated against the melting points of $\mathrm{NaCl}\left(801{ }^{\circ} \mathrm{C}\right)$ and $\mathrm{Au}\left(1063{ }^{\circ} \mathrm{C}\right)$. The furnace was controlled by an a-c Wheatstone bridge controller capable of maintaining temperature to at least $\pm 2{ }^{\circ} \mathrm{C}$. Specimens were quenched into an ice-cooled brass cold finger which constitutes the lower portion of the furnace. X-ray patterns were made using a highangle Geiger counter-diffractometer and nickelfiltered $\mathrm{Cu}$ radiation at a $1 / 4^{\circ} 2 \theta / \mathrm{min}$ scanning rate. Reported unit cell data are considered accurate to about \pm 2 in the last decimal place listed.

\section{Experimental Results}

A portion of the $\mathrm{BaO}$-"iron oxide" pseudobinary in the vicinity (high baria portion) of the $1: 1$ cationcation compound is shown in figure 1. The diagram was constructed from the data in table 1 . It is emphasized that the diagram represents stability of phases present (determined by room temperature $\mathrm{x}$-ray patterns) as a function of starting $\mathrm{Ba}: \mathrm{Fe}$ ratio. $\mathrm{Ab}$ solute compositions involving $\mathrm{Ba}: \mathrm{Fe}^{4+}: \mathrm{Fe}^{3+}$ ratios belonging to the $\mathrm{BaO}-\mathrm{Fe}_{2} \mathrm{O}_{3}-{ }^{-} \mathrm{FeO}_{2}$ " ternary are not indicated.

The $1: 1$ hexagonal $\mathrm{BaTiO}_{3}$-like phase, $\mathrm{BaFeO}_{3-X}$ $(a=5.676 \AA, c=13.934 \AA)$, exists at low temperatures as previously observed by others. An indexed powder pattern is provided in table 2. MacChesney et al. [1], reported the hexagonal form, $\mathrm{BaFeO}_{2.82}$ and $\mathrm{BaFeO}_{2.84}$, at low temperatures in 1 atm $\mathrm{O}_{2}$ and air, respectively. The value of $X$ for the $\mathrm{BaFeO}_{3-X}$ in this study is, therefore, probably within the $0.20-0.15$ range. Above approximately $960^{\circ} \mathrm{C}$ the phase transforms to a perovskite-like form, probably by further

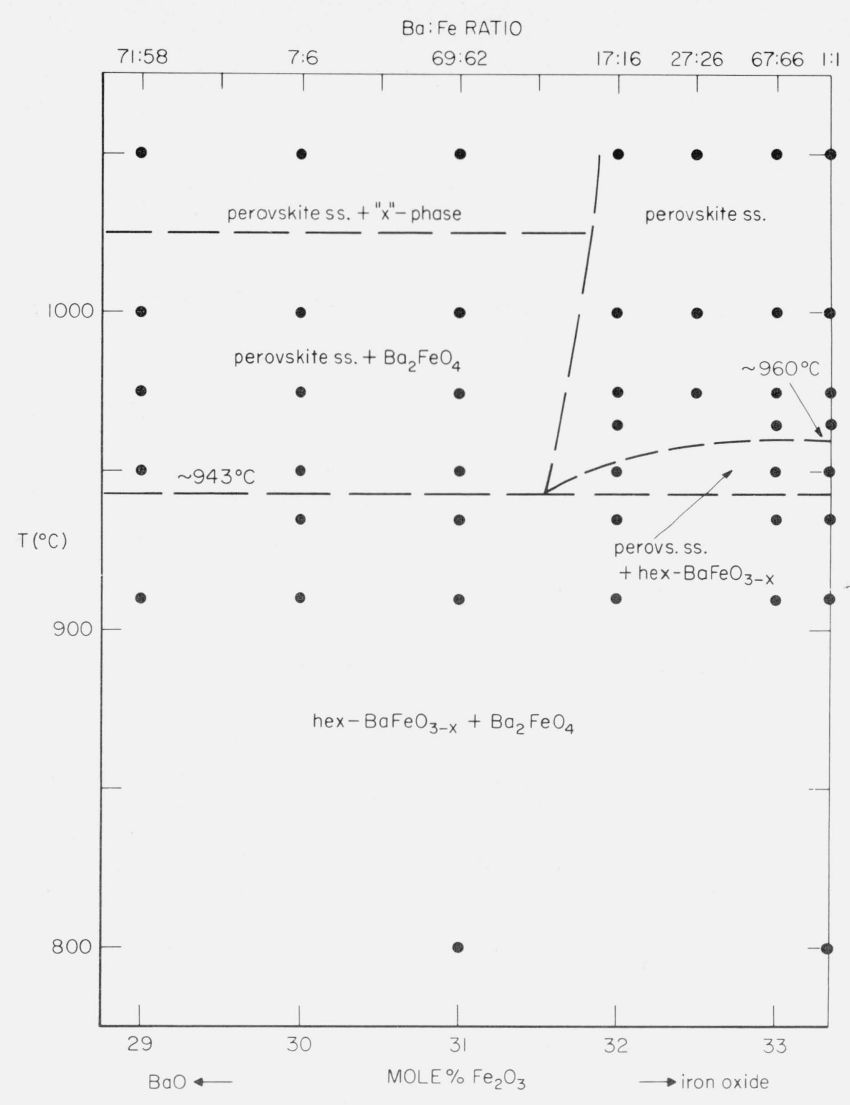

Figure 1. Subsolidus relations at 1 atm $\mathrm{O}_{2}$ for that portion of the $\mathrm{BaO}$ "iron oxide" pseudobinary near the 1:1 barium-iron ratio.

Absolute $\mathrm{Ba}-\mathrm{Fe}-\mathrm{O}$ concentrations are not indicated.

reduction of part of the available $\mathrm{Fe}^{4+}$ to $\mathrm{Fe}^{3+}$. The powder pattern, given in table 3 , bears a superficial resemblance to a tetragonal perovskite but is rather diffuse and contains a number of extra lines. This phase may be represented as $\mathrm{BaFeO}_{3-X^{\prime}}$, where $0.5>X^{\prime}>0$ and $X^{\prime}>X_{\text {hex }}$, where $X_{\text {hex }}$ refers to the oxygen deficiency in the hexagonal form. It is not $\mathrm{Ba}_{2} \mathrm{Fe}_{2} \mathrm{O}_{5},\left(\mathrm{BaFeO}_{2.5}, X^{\prime}=0.5\right)$, a brownmillerite-like compound also reported by MacChesney et al. [1]. Within this temperature range, however, a $\mathrm{Ba}_{2} \mathrm{Fe}_{2} \mathrm{O}_{5}$ like phase was found to exist in air. Although the transformation near $960{ }^{\circ} \mathrm{C}$ in this study correlates well with that observed by Mori [9] $\left(>950^{\circ} \mathrm{C}\right)$, a definitive correlation of phases could not be made. It seems very likely, however, that Malinofsky and Kedesdy [4] observed the $\mathrm{BaFeO}_{3-X^{\prime}}$ of this study or one of the tetragonal phases reported by Mori when they heated and slow-cooled the hexagonal form from $1275{ }^{\circ} \mathrm{C}$ in oxygen.

Hexagonal $\mathrm{BaFeO}_{3-X}$ does not appear to form solid solutions in the high baria portion of the system below $960{ }^{\circ} \mathrm{C}$. Changes in oxygen stoichiometry may occur as a function of temperature to $960^{\circ} \mathrm{C}$. Cell parameters, however, do not change from 800 to $960{ }^{\circ} \mathrm{C}$ and it is, therefore, expected that change in oxygen concentration within this temperature range is limited. Below approximately $943{ }^{\circ} \mathrm{C}$, the phase assemblage consists 
TABLE 1. Experimental data for compositions in the system $\mathrm{BaO}$-“iron oxide" at 1 atm oxygen

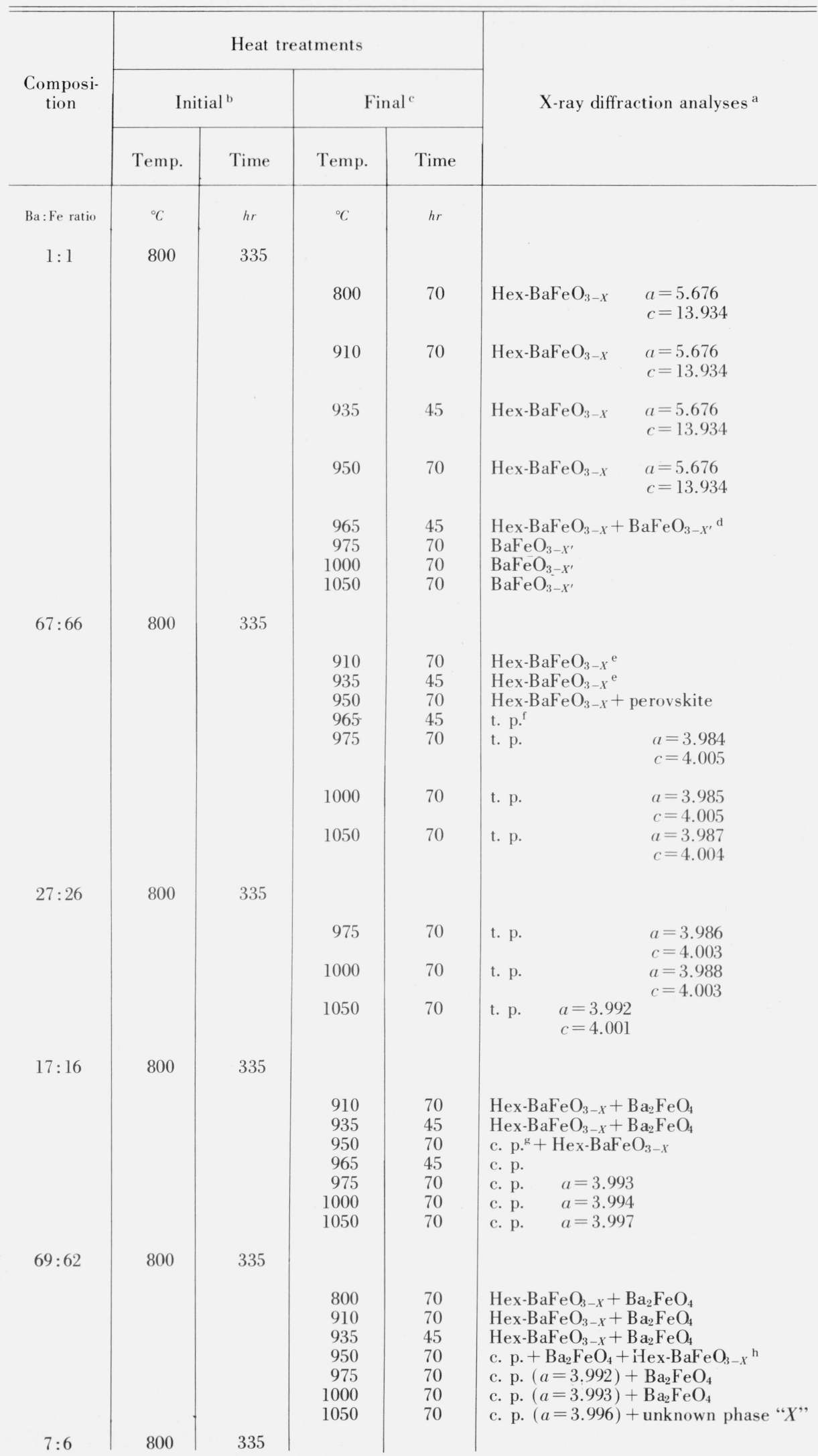


TABLE 1. Experimental data for compositions in the system $\mathrm{BaO}$ "iron oxide" at 1 atm oxygen-Continued

\begin{tabular}{|c|c|c|c|c|c|}
\hline \multirow{3}{*}{$\begin{array}{c}\text { Composi- } \\
\text { tion }\end{array}$} & \multicolumn{4}{|c|}{ Heat treatments } & \multirow{3}{*}{ X-ray diffraction analyses ${ }^{a}$} \\
\hline & \multicolumn{2}{|c|}{ Initial $^{\mathrm{b}}$} & \multicolumn{2}{|c|}{ Final $^{c}$} & \\
\hline & Temp. & Time & Temp. & Time & \\
\hline $\mathrm{Ba}: \mathrm{Fe}$ ratio & ${ }^{\circ} \mathrm{C}$ & $h r$ & $\begin{array}{c}{ }^{\circ} \mathrm{C} \\
910 \\
935 \\
950 \\
975 \\
1000 \\
1050\end{array}$ & $\begin{array}{c}h r \\
70 \\
45 \\
70 \\
70 \\
70 \\
70\end{array}$ & 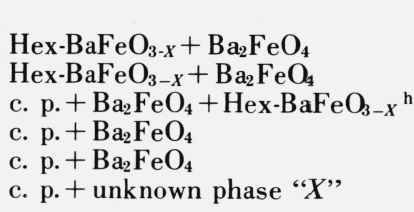 \\
\hline $71: 58$ & 800 & 335 & $\begin{array}{r}910 \\
950 \\
975 \\
1000 \\
1050\end{array}$ & $\begin{array}{l}70 \\
70 \\
70 \\
70 \\
70\end{array}$ & $\begin{array}{l}\mathrm{Hex}-\mathrm{BaFeO}_{3-X}+\mathrm{Ba}_{2} \mathrm{FeO}_{4} \\
\text { c. p. }+\mathrm{Ba}_{2} \mathrm{FeO}_{4} \\
\text { c. p. }+\mathrm{Ba}_{2} \mathrm{FeO}_{4} \\
\text { c. p. }+\mathrm{Ba}_{2} \mathrm{FeO}_{4} \\
\text { c. p. }+ \text { unknown phase " } X \text { " }\end{array}$ \\
\hline
\end{tabular}
a Phases identified are given in the order of amount present at room temperature. The
phases are not necessarily those present at the temperature to which the specimen was heated.

eated in air in Au.

Heated in 1 atm oxygen in Au.

TABLE 2. X-ray diffraction powder data for the hexagonal $\mathrm{BaTiO}_{3}$-like phase, $\mathrm{BaFeO}_{3-\mathrm{x}}{ }^{\mathrm{a}}$

\begin{tabular}{|c|c|c|c|c|}
\hline$d_{\mathrm{obs}}^{\mathrm{b}}$ & $I / I_{0} c$ & $\frac{1}{d_{\text {calc }}^{2}}$ & $\frac{1}{d_{\mathrm{obs}}^{2}}$ & $h k l^{d}$ \\
\hline $\begin{array}{l}4.017 \\
3.376\end{array}$ & $\begin{array}{r}9 \\
23\end{array}$ & $\begin{array}{r}0.0620 \\
0877\end{array}$ & $\begin{array}{r}0.0620 \\
0878\end{array}$ & 102 \\
\hline \multirow{2}{*}{2.838} & \multirow{2}{*}{100} & .1238 & \multirow{2}{*}{.1242} & 104 \\
\hline & & .1242 & & 110 \\
\hline \multirow{2}{*}{2.421} & \multirow{2}{*}{13} & .1705 & \multirow{2}{*}{.1706} & 113 \\
\hline & & .1707 & & 201 \\
\hline 2.322 & 15 & .1854 & 1855 & 006 \\
\hline 2.318 & 17 & .1861 & .1861 & 202 \\
\hline 2.173 & 21 & .2119 & .2119 & 203 \\
\hline 2.009 & 28 & .2479 & .2479 & 204 \\
\hline \multirow{2}{*}{1.8433} & \multirow{2}{*}{12} & .2943 & \multirow{2}{*}{.2943} & 205 \\
\hline & & .2948 & & 211 \\
\hline 1.7954 & 8 & .3103 & .3102 & 212 \\
\hline 1.7251 & 7 & .3361 & .3361 & 213 \\
\hline \multirow[t]{2}{*}{1.6388} & \multirow[t]{2}{*}{28} & .3721 & \multirow{2}{*}{.3724} & 214 \\
\hline & & .3725 & & 300 \\
\hline \multirow{2}{*}{1.5457} & \multirow{2}{*}{8} & .4185 & \multirow{2}{*}{.4186} & 215 \\
\hline & & .4188 & & 303 \\
\hline \multirow{2}{*}{1.4837} & \multirow{2}{*}{ e 2} & .4538 & \multirow{2}{*}{.4543} & 118 \\
\hline & & .4549 & & 304 \\
\hline 1.4765 & 5 & .4586 & .4587 & 109 \\
\hline 1.4209 & 7 & .4952 & .4953 & 208 \\
\hline 1.4190 & 12 & .4966 & .4966 & 220 \\
\hline \multirow[t]{2}{*}{1.3573} & \multirow[t]{2}{*}{5} & .5429 & \multirow[t]{2}{*}{.5428} & 223 \\
\hline & & .5564 & & $1,0,10$ \\
\hline \multirow[t]{2}{*}{1.3389} & \multirow[t]{2}{*}{ e 3} & .5579 & \multirow[t]{2}{*}{.5578} & 306 \\
\hline & & .5586 & & 312 \\
\hline 1.3084 & 6 & .5844 & .5842 & 313 \\
\hline 1.2696 & 8 & .6204 & .6204 & 314 \\
\hline 1.2242 & 3 & .6673 & .6673 & 401 \\
\hline \multirow{2}{*}{1.2106} & \multirow{2}{*}{6} & .6820 & \multirow{2}{*}{.6824} & 226 \\
\hline & & .6828 & & 402 \\
\hline 1.1881 & 4 & .7085 & .7085 & 403 \\
\hline 1.1589 & 4 & .7446 & .7446 & 404 \\
\hline 1.1245 & 3 & .7909 & .7909 & 405 \\
\hline 1.0727 & 8 & .8691 & 8691 & 410 \\
\hline $\begin{array}{l}\text { terplane } \\
\text { sserved }\end{array}$ & & $\begin{array}{c}{ }^{\mathrm{d}} \text { Indexe } \\
a=5.676 \\
\text { e }\end{array}$ & $\begin{array}{l}\text { basis of } \\
13.934 \AA\end{array}$ & \\
\hline
\end{tabular}

dPerovskite-like phase.

${ }^{e} \mathrm{Ba}_{2} \mathrm{FeO}_{4}$ in insufficient amount to detect.

't. p. = tetragonal perovskite.

c. p. = cubic perovskite

${ }^{\mathrm{h}}$ Incomplete reaction.

TABLE 3. X-ray diffraction powder data for the perovskite-like phase, $\mathrm{BaFeO}_{3-\mathrm{x}^{\prime}} \mathrm{a}^{-}$

\begin{tabular}{r|r|r}
\hline \hline line & $d^{\mathrm{b}}$ & $I / I_{0}{ }^{\mathrm{c}}$ \\
\hline & & \\
1 & 4.09 & $\mathrm{~d} 2$ \\
2 & 4.01 & 6 \\
3 & 3.98 & 7 \\
4 & 2.91 & $\mathrm{~d} 9$ \\
5 & 2.86 & $\mathrm{~d}, \mathrm{e}$ \\
6 & 2.82 & 100 \\
7 & 2.31 & 4 \\
8 & 2.30 & 15 \\
9 & 2.02 & $\mathrm{~d} 3$ \\
10 & 2.00 & 9 \\
11 & 1.989 & 15 \\
12 & 1.789 & 4 \\
13 & 1.781 & 4 \\
14 & 1.633 & 10 \\
15 & 1.627 & 18 \\
16 & 1.413 & 11 \\
17 & 1.408 & $\mathrm{~d} 8$ \\
\hline
\end{tabular}

a Preparèd at $1000^{\circ} \mathrm{C}, 1$ atm $\mathrm{O}_{2}$.

b Interplanar spacing, $\AA$.

c Observed intensity.

d Broad.

e Appears only after long exposure to air.

of hex- $\mathrm{BaFeO}_{3-X}$ and $\mathrm{Ba}_{2} \mathrm{FeO}_{4}$. The latter phase is extremely sensitive to moisture and tends to deteriorate when exposed to air and during $\mathrm{x}$-ray analysis. The compound was made from a $4 \mathrm{BaCO}_{3}: \mathrm{Fe}_{2} \mathrm{O}_{3}$ mixture at $900{ }^{\circ} \mathrm{C}$ in air and at $900{ }^{\circ} \mathrm{C}$ in 1 atm $\mathrm{O}_{2}$. A portion of its powder pattern, indexed by analogy with $\mathrm{K}_{2} \mathrm{SO}_{4}$ is given in table 4 . The phase is orthorhombic with $a=5.93 \AA, b=10.36 \AA$, and $c=7.64 \AA$.

Above $943{ }^{\circ} \mathrm{C}$, phase assemblages are quite interesting, as true perovskite-like phases appear. At the 67:66 $\mathrm{Ba}: \overline{\mathrm{F} e}$ ratio single-phase tetragonal perovskites may be quenched from 960 to $1050^{\circ} \mathrm{C}$. The indexed powder 
TABLE 4. X-ray diffraction powder data for the compound, $\mathrm{Ba}_{2} \mathrm{FeO}_{4}{ }^{\text {a }}$

\begin{tabular}{|c|c|c|c|c|}
\hline$d_{\mathrm{obs}}^{\mathrm{b}}$ & $I / I_{0}{ }^{\mathrm{c}}$ & $\frac{1}{d_{\text {calc }}^{2}}$ & $\frac{1}{d_{\mathrm{obs}}^{2}}$ & $h k l^{\mathrm{d}}$ \\
\hline 4.279 & 10 & $\begin{array}{r}0.0544 \\
.0549\end{array}$ & 0.0546 & $\begin{array}{l}021 \\
111\end{array}$ \\
\hline $\begin{array}{l}3.824 \\
3.581 \\
3.474 \\
3.211 \\
3.149\end{array}$ & $\begin{array}{l}12 \\
12 \\
64 \\
33 \\
21\end{array}$ & $\begin{array}{l}.0685 \\
.0779 \\
.0828 \\
.0970 \\
.1010\end{array}$ & $\begin{array}{l}.0684 \\
.0780 \\
.0829 \\
.0970 \\
.1009\end{array}$ & $\begin{array}{l}002 \\
012 \\
121 \\
102 \\
031\end{array}$ \\
\hline 3.069 & 100 & $\begin{array}{l}.1058 \\
.1063\end{array}$ & .1062 & $\begin{array}{l}022 \\
112\end{array}$ \\
\hline $\begin{array}{l}2.985 \\
2.964\end{array}$ & $\begin{array}{l}91 \\
71\end{array}$ & $\begin{array}{l}.1123 \\
.1138\end{array}$ & $\begin{array}{l}.1122 \\
.1138\end{array}$ & $\begin{array}{l}130 \\
200\end{array}$ \\
\hline
\end{tabular}

a Prepared at $900^{\circ} \mathrm{C}$ in air.

' Interplanar spacing, $\AA$

c Observed intensity.

${ }^{d}$ Indexed on the basis of an orthorhombic cell with $a=5.93 \AA, b=10.36 \AA, c=7.64 \AA$

pattern of a typical tetragonal phase is given in table 5. Single-phase tetragonal perovskites can also be quenched from above $960{ }^{\circ} \mathrm{C}$ at the $27: 26 \mathrm{Ba}: \mathrm{Fe}$ ratio. Tetragonal perovskites at the 67:66 ratio transform to cubic on heating near $75^{\circ} \mathrm{C}$ while those at the $27: 26$ ratio transform near $45^{\circ} \mathrm{C}$. Single phase cubic perovskites are obtained at room temperature at the 17:16 $\mathrm{Ba}: \mathrm{Fe}$ ratio. An indexed pattern of a typical cubic phase is given in table 6 . Figure 2 shows the variation of room temperature-determined cell parameters with temperature and composition from 975 to 1050 ${ }^{\circ} \mathrm{C}$. Compositions more BaO-rich than 17:16 yield cubic perovskite solid-solution plus $\mathrm{Ba}_{2} \mathrm{FeO}_{4}$ between

TABLE 5. X-ray diffraction data for the tetragonal perovskite at the $67: 66$ Ba-Fe ratio $^{a}$

\begin{tabular}{|c|c|c|c|c|}
\hline$d_{o b s}^{b}$ & $I / I_{o}{ }^{c}$ & $\frac{1}{d_{\text {calc }}^{2}}$ & $\frac{1}{d_{\mathrm{obs}}^{2}}$ & $h k l^{d}$ \\
\hline 4.003 & 8 & 0.0624 & 0.0624 & 001 \\
\hline 3.981 . & 12 & .0630 & .0631 & 100 \\
\hline 2.824 & 100 & .1253 & .1254 & 101 \\
\hline 2.818 & 90 & .1259 & .1259 & 110 \\
\hline 2.304 & 29 & 1883 & .1884 & 111 \\
\hline 2.002 & 13 & .2494 & .2494 & 002 \\
\hline 1.9922 & 26 & .2519 & .2520 & 200 \\
\hline 1.7892 & 4 & .3124 & .3124 & 102 \\
\hline 1.7836 & 7 & .3142 & .3143 & 201 \\
\hline 1.7823 & 5 & .3148 & .3148 & 210 \\
\hline 1.6321 & 18 & .3754 & .3754 & 112 \\
\hline 1.6281 & 35 & .3772 & .3772 & 211 \\
\hline 1.4124 & 13 & .5013 & .5013 & 202 \\
\hline 1.4090 & 14 & .5037 & .5038 & 220 \\
\hline 1.3349 & 4 & .5612 & .5612 & 003 \\
\hline 1.3284 & 4 & .5667 & .5667 & 300 \\
\hline 1.2657 & 6 & .6242 & .6242 & 103 \\
\hline 1.2606 & 10 & .6290 & .6293 & $\left\{\begin{array}{l}301 \\
310\end{array}\right.$ \\
\hline 1.2064 & 4 & 6871 & .6872 & 113 \\
\hline 1.2021 & 5 & .6920 & .6921 & 311 \\
\hline 1.1524 & 7 & .7531 & .7531 & 222 \\
\hline 1.0684 & 6 & .8760 & .8760 & 213 \\
\hline 1.0666 & 10 & .8791 & .8791 & 312 \\
\hline 1.0655 & 8 & 8809 & .8809 & 321 \\
\hline
\end{tabular}

${ }^{a}$ Prepared at $1000{ }^{\circ} \mathrm{C}, 1$ atm $\mathrm{O}_{2}$.

${ }^{b}$ Interplanar spacing, $\AA$.

c Observed intensity.

${ }_{d}$ Indexed on the basis of a tetragonal cell with $a=3.985 \AA, c=4.005 \AA$.

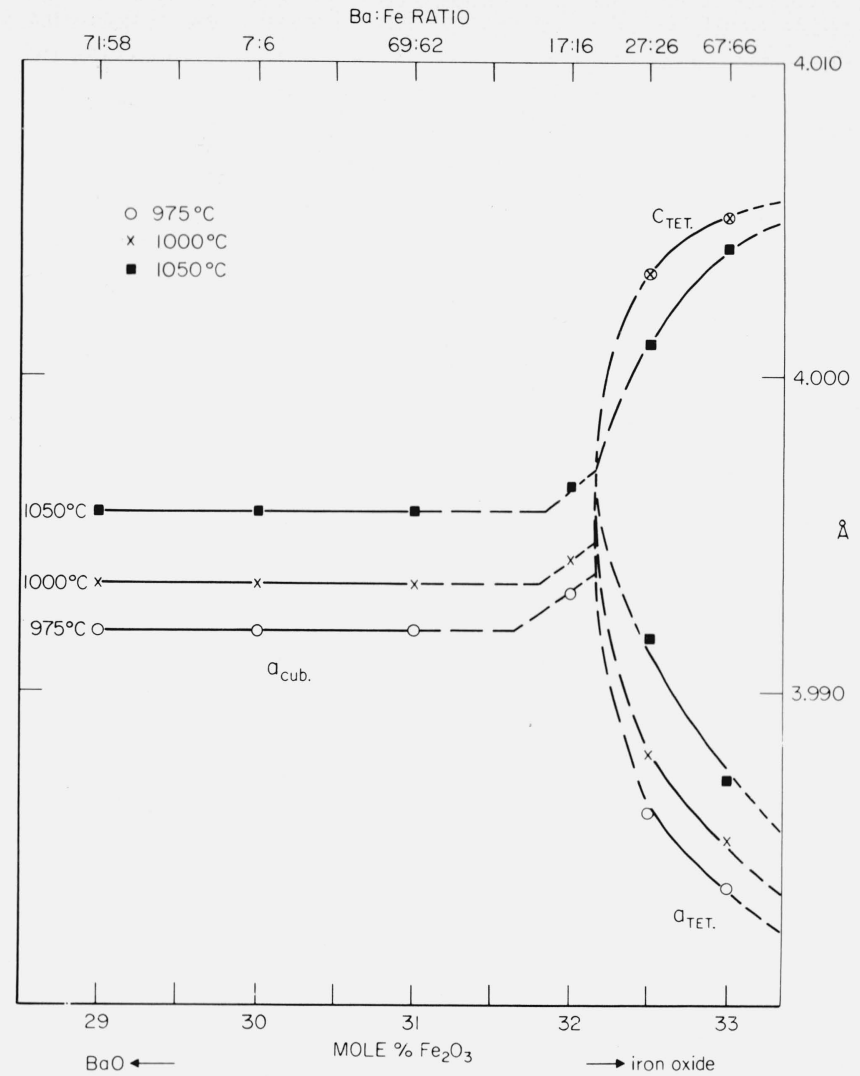

FIGURE 2. Variation of room temperature-determined cell parameters with temperature and composition for cubic and tetragonal barium-iron perovskites.

TABLE 6. X-ray powder diffraction data for the cubic perovskite at the 17:16 Ba-Fe ratio ${ }^{a}$

\begin{tabular}{l|r|r|r|l}
\hline \hline & & & & \\
$d_{\text {obs }}{ }^{b}$ & $I / I_{o}{ }^{c}$ & $\frac{1}{d_{\text {calc }}^{2}}$ & $\frac{1}{d_{\text {obs }}^{2}}$ & $h k l^{d}$ \\
& & & & \\
& & & & \\
3.994 & 13 & 0.0627 & 0.0627 & 100 \\
2.824 & 100 & .1254 & .1253 & 110 \\
2.306 & 23 & .1880 & .1880 & 111 \\
1.9972 & 34 & .2507 & .2507 & 200 \\
1.7862 & 8 & .3134 & .3134 & 210 \\
1.6308 & 37 & .3761 & .3760 & 211 \\
1.4122 & 17 & .5014 & .5015 & 220 \\
1.3315 & 4 & .5641 & .5641 & 300 \\
1.2631 & 12 & .6268 & .6268 & 310 \\
1.2043 & 5 & .6895 & .6895 & 311 \\
1.1530 & 6 & .7522 & .7522 & 222 \\
1.0675 & 13 & .8775 & .8775 & 321 \\
0.99858 & 3 & 1.0029 & 1.0029 & 400 \\
.96875 & 3 & 1.0656 & 1.0656 & $410 / 322$ \\
.94146 & 5 & 1.1283 & 1.1282 & $411 / 330$ \\
.91635 & 3 & 1.1910 & 1.1909 & 331 \\
.89313 & 5 & 1.2536 & 1.2537 & 420 \\
\hline
\end{tabular}

${ }^{a}$ Prepared at $1000{ }^{\circ} \mathrm{C}, 1$ atm $\mathrm{O}_{2}$.

${ }^{b}$ Interplanar spacing, $\AA$.

${ }^{c}$ Observed intensity.

${ }^{d}$ Indexed on the basis of a cubic cell with $a=3.994$, $\AA$.

$943^{\circ}$ and about $1025{ }^{\circ} \mathrm{C}$. Above $1025{ }^{\circ} \mathrm{C}$ an unknown phase exists with the perovskite and is characterized by the appearance of lines with $d=4.19,3.84,3.66$, $3.23,3.12$, and $2.97 \AA$ in the low angle region. Variation of cell parameters as a function of cation-cation 
ratio and temperature in the limited homogeneity region is a complex feature which can be deciphered only with knowledge of accurate $\mathrm{Fe}^{4+}: \mathrm{Fe}^{3+}$ ratios. At a fixed ratio, cell expansion with increasing temperature is probably a result of increased reduction of $\mathrm{Fe}^{4+}$ to $\mathrm{Fe}^{3+}$ with a corresponding decrease in oxygen content. Changes with cation-cation ratio at fixed temperature may be much more complicated than merely being due to variation in barium content. Increasing barium appears to cause expansion of $a_{\text {tet }}$ and contraction of $c_{\text {tet }}$ and $a_{\text {cubic }}$ at fixed temperature in the single-phase region. Furthermore, it is highly unlikely that a stable perovskite structure can accommodate interstitial barium. At $1000{ }^{\circ} \mathrm{C}$, the single-phase cubic perovskite, for example, contains an excess of about $1.3 \mathrm{~mol}$ percent $\mathrm{BaO}$ (in terms of $\mathrm{BaO}: \mathrm{Fe}_{2} \mathrm{O}_{3}$ ) and its composition might be described as $\mathrm{Ba}_{17} \mathrm{Fe}_{16} \mathrm{O}_{N}$ where $N=49-X$. This may be more appropriately written as $\mathrm{BaFe}_{16 / 17} \mathrm{O}_{N / 17}$ which now indicates iron and oxygen vacancies rather than barium interstitials. The value of $X$ will, of course, depend on the $\mathrm{Fe}^{4+}: \mathrm{Fe}^{3+}$ ratio in the phase. Starting at the $\mathrm{BaFeO}_{3-X^{\prime}}$ phase, increasing amounts of barium at constant temperature will tend to increase the concentration of iron and oxygen vacancies. Increasing iron and $\mathrm{O}^{=}$vacancies should tend to expand the structure. Although unit cell volumes increase initially with increasing barium content, the apparent $a$ cubic contraction associated with single phases from near the 17:16 ratio to the two phase region suggests a second mechanism operating simultaneously. A plausible hypothesis involves the general equilibrum

$$
2 \mathrm{Fe}^{3+}+\frac{1}{2} \mathrm{O}_{2} \rightarrow 2 \mathrm{Fe}^{4+}+\mathrm{O}^{2-} \text {. }
$$

Physically, this mechanism would operate in the following manner. As iron and $\mathrm{O}^{=}$vacancies are created by addition of barium, the concentration level of the $\mathrm{O}=$ vacancies would be decreased if some of the available $\mathrm{Fe}^{3+}$ is oxidized to $\mathrm{Fe}^{4+}$. The total number of iron vacancies would not be affected but the $\mathrm{Fe}^{4+}: \mathrm{Fe}^{3+}$ ratio, and consequently $\mathrm{O}=$ concentration, would increase. Cell contraction, as observed, might result.

Data pertinent to temperatures above $1050{ }^{\circ} \mathrm{C}$ could not be obtained in this study because of problems with container materials. Above the melting, point of $\mathrm{Au}$, platinum tubes were used as containers for equilibration runs. In gold, hex- $\mathrm{BaFeO}_{3-X}$ is not stable above $960{ }^{\circ} \mathrm{C}$ and 1 atm $\mathrm{O}_{2}$. In platinum, however, a hexagonal $\mathrm{BaFeO}_{3-X}$-like phase does exist above $960{ }^{\circ} \mathrm{C}$ and persists at elevated temperatures to at least $1300{ }^{\circ} \mathrm{C}$. The phase is normally admixed with perovskite-like material but tends to predominate with increasing firing time. Consistent and reproducible equilibria data are difficult to obtain. It is hardly likely that hex- $\mathrm{BaFeO}_{3-X}$ converts at $960{ }^{\circ} \mathrm{C}$ to perovskitelike $\mathrm{BaFeO}_{3-X}$, which in turn transforms at some temperature $>1050{ }^{\circ} \mathrm{C}$ back to a hex- $\mathrm{BaFeO}_{3-X^{\prime \prime}}$ phase. This is apparent, especially in view of the data of MacChesney et al. [1], suggesting the existence of an orthorhombic brownmillerite-like $\mathrm{Ba}_{2} \mathrm{Fe}_{2} \mathrm{O}_{5}$ which might be expected to form at sufficiently elevated temperatures in $\mathrm{O}_{2}$. Goto and Takada [7] using $\mathrm{Pt}$ containers and $\mathrm{l}$ atm $\mathrm{O}_{2}$ reported a cubic $2 \mathrm{BaO} \cdot \mathrm{Fe}_{2} \mathrm{O}_{3}$ phase with a melting point near $1370{ }^{\circ} \mathrm{C}$. As pure $\mathrm{Ba}_{2} \mathrm{Fe}_{2} \mathrm{O}_{5}$ is not cubic and the reported $a=8.07 \AA$ parameter is approximately $2 \times a_{\text {cubic }}$ perovskite, a value which may be used to index a hexagonal $\mathrm{BaTiO}_{3}$ like phase, the compound was probably erroneously identified. It is likely that the phase observed was of the hex- $\mathrm{BaFeO}_{3-X}$ type. More interesting, however, is the stability of the compound to a congruent melting point in 1 atm $\mathrm{O}_{2}$ and the exclusion of a stability range for a perovskite-like $\mathrm{BaFeO}_{3-X^{\prime}}$. These reported data and the inconsistent data above $1050{ }^{\circ} \mathrm{C}$ in this study have but one common denominator, platinum containers. It is, therefore, suggested that in the presence of $\mathrm{Pt}$, a reaction occurs resulting in the stabilization of a hexagonal $\mathrm{BaTiO}_{3}$-like phase containing $\mathrm{Pt}^{4+}$. Hexagonal phases containing $\mathrm{Pt}^{4+}$ are not unusual and have been reported by Dickinson et al. [10], Blattner et al. [11], and Stratton [12]. If platinum does indeed tend to stabilize the hexagonal form, it is not surprising that the cubic and tetragonal high temperature perovskites herein reported have not been previously observed, as most experiments involving synthesis of materials are conducted using Pt-containers. Furthermore, chemical analyses for $\mathrm{Fe}^{4+}: \mathrm{Fe}^{3+}$ ratios, when $\mathrm{Pt}$ is present, would lead to erroneous oxygen ion concentrations.

\section{Summary}

Phase relations in the $\mathrm{BaO}$-"iron oxide" pseudobinary in the vicinity of the $1: 1$ cation-cation ratio were determined in 1 atm $0_{2}$ and between 800 to $1050{ }^{\circ} \mathrm{C}$. Below $960{ }^{\circ} \mathrm{C}$ a hex $-\mathrm{BaTiO}_{3}$-like phase, $\mathrm{BaFeO}_{3-X}$ exists. Above $960{ }^{\circ} \mathrm{C}$, this phase transforms to a perovskite-like $\mathrm{BaFeO}_{3-X^{\prime}}$. Specimens quenched from the 960 to $1050{ }^{\circ} \mathrm{C}$ range and having $\mathrm{Ba}: \mathrm{Fe}$ ratios of 67:66 and 27:26 yield single-phase tetragonal perovskite at room temperature. Single-phase cubic perovskite can be quenched from this temperature range at the 17:16 ratio. $\mathrm{Hex}-\mathrm{BaTiO}_{3}$-like phases were observed in specimens heated above $1050{ }^{\circ} \mathrm{C}$ in $\mathrm{Pt}$ containers. These are considered to be products of a $\mathrm{Pt}$-specimen reaction.

\section{References}

[1l MacChesney, J. B., Potter, J. F., Sherwood, R. C., and Williams, H. J., J. Chem. Phys. 43, 3317 (1965).

[2] Gallagher, P. K., MacChesney, J. B., and Buchanan, D. N. E., J. Chem. Phys. 43, 516 (1965).

[3] Erchak, M., Fankuchen, T., and Ward, R., J. Am. Chem. Soc. 68, 2085 (1946).

[4] Malinofsky, W. W., and Kedesdy, H., J. Am. Chem. Soc. 76, 3090 (1954).

[5] Burbank, R. D., and Evans, H. T., Acta Cryst. 1, 330 (1948).

[6] Gushee, B. E., Katz, L., and Ward, R., J. Am. Chem. Soc. 79, 5601 (1957).

[7] Goto, Y., and Takada, T., J. Am. Ceram. Soc. 43, 150 (1960).

[8] Mori, S., J. Am. Ceram. Soc. 48, 165 (1965).

[9] Mori, S., J. Am. Ceram. Soc. 49, 600 (1966).

[10] Dickinson, J. G., Katz, L., and Ward, R., J. Am. Chem. Soc. 83, 3026 (1961).

[11] Blattner, H., Gränicher, H., Kanzig, W., and Merz, W., Helv. Phys. Acta 21, 341 (1948).

[12] Stratton, W. O., J. Chem. Phys. 19, 33 (1951).

(Paper 73A4-561) 